Check for updates

Washington DC

bobroehr@aol.com

Cite this as: BMJ 2020;370:m3393 http://dx.doi.org/10.1136/bmj.m3393 Published: 21 September 2020

\section{Bringing drug production home: how the US is rebuilding the drug supply chain after covid-19}

\author{
The US government and private sector are committing billions of dollars to create more secure supply \\ chains and bring a portion of that manufacturing capacity back home. Bob Roehr reports.
}

\section{Bob Roehr freelance journalist}

"The problem is simply that, across the world, we have sweatshop labor, we have pollution havens, we have tax havens, which have pulled our manufacturing offshore, particularly for pharmaceuticals," US trade representative Peter Navarro told reporters earlier this month. It was to mark an executive order signed by President Donald Trump on 6 August officially setting a policy to restore production of essential medicines to within the US. ${ }^{1}$

The pandemic had highlighted a trend that had been climbing for the past two decades: the US, like many countries, gets most of its medicines from outside its borders. Today, $92 \%$ of all US prescriptions filled are generic drugs, and almost none is produced in the US. That's a shock considering that, as recently as the 1990s, the US, Europe, and Japan manufactured about $90 \%$ of the key ingredients for medicines between them. ${ }^{2}$

"With generic drugs, it's all about costs," says Joseph Glajch, a 40 year veteran of the pharmaceutical industry and now an independent consultant. The use of small molecule generics had expanded greatly in the 1980 in the US as key drugs came off patent and branded successors offered few advantages to justify their added cost.

Production shifted overseas, particularly to India and China, which offered lower costs, an educated workforce, laxer environmental controls, and government subsidies, particularly for exports. The shift was more gradual in Europe, in part because the price of branded drugs is lower and hence the savings in shifting to a generic is less, but also because of national policies that subsidized local production.

With global supply chains in general disrupted by the covid-19 pandemic, many countries have concerns across a broad number of business sectors. Japan's coronavirus recovery program has set aside \$2.2 billion to help companies build or relocate facilities back to Japan and other countries, including the US.

Even India, despite being called by some "the pharmacy of the world" with $\$ 17.3$ billion in pharmaceutical exports, ${ }^{3}$ has its own concerns about access to drugs. When Trump touted hydroxychloroquine as a treatment for covid-19 and sparked a run on the malaria drug, India imposed export controls to guarantee an adequate supply for its own needs. A later border skirmish with China drew renewed attention to its reliance on China for about $70 \%$ of the active ingredients used by its pharmaceutical industry. The dramas of 2020 are forcing India to lessen if not eliminate that reliance. ${ }^{4}$

Meanwhile, private European drug makers announced plans to expand production capacities in Europe for everything from basic chemicals to medical glass, but generally on a more modest scale than is seen elsewhere.

Covid-19 has accelerated trends to lessen reliance on the likes of China and India and to develop supply chains that are more secure, and the US healthcare industry is no different.

\section{Homegrown needs}

The Biomedical Advanced Research and Development Authority (BARDA), which is part of the US

Department of Health and Human Services, has been making long term purchase agreements for years, but spending really ramped up in December 2019 with a \$285 million investment in Paratek Pharma to set up an antibiotic production line in the US. With the onset of the pandemic, the government had been pouring billions into covid-19 vaccine and generic drug production capacity to lessen dependence on China and India.

Civica $\mathrm{Rx}$ is a relatively new non-profit company that was formed to address issues of drug shortages and quality control. It has the support of leading philanthropic organizations such as the Bill and Melinda Gates Foundation, healthcare providers such as Intermountain Health, and the Veterans Health Administration, groups that administer about half the hospital beds in the US. 56

The company initially planned to make bulk purchases and then move into direct production and distribution of key pharmaceuticals. "We made two really important decisions that worked out very well during the covid-19 crisis. One was, we were never going to source our pharmaceutical ingredients from China, and the other was, we were going to carry six months of safety stock for all of the drugs that we carry for our membership group," Civica board chair Dan Liljenquist told The BMJ.

Civica asks members to commit to purchase half their volume of a particular drug from the organization for at least five years on a cost-plus model where the company is assured a profit over its costs of manufacturing. That will assure volume and a fair profit for the manufacturer to stabilize the market. And it asks that members purchase the balance of their needs elsewhere. "We do not want to be the only source for each drug," Liljenquist adds, "The goal 
here is to bring competition to the market at a fair price.”

\section{Federal funds}

Trump's executive order sets out a series of ambitious timelines to identify biomedical priorities and plans to reduce US reliance on foreign supply chains. It also contains provisions to opt out from such mandates if the costs and conditions are too onerous.

The plan builds on much that has already taken place in recent years. BARDA is perhaps the biggest, yet least known, player. Its billion dollar contracts to Astra/Zeneca and others support clinical trials for covid-19 vaccine development and require that some or all of a final product be manufactured in and initially distributed in the US, though they do not preclude simultaneous development of parallel facilities elsewhere.

One of the most intriguing projects is the \$354 million (potentially $\$ 801$ million over 10 years) contract BARDA has handed to non-profit start-up company Phlow Corp. It will build a facility in Richmond, Virginia, to produce active pharmaceutical ingredients (APIs) from scratch using “continuous flow” production techniques (basically doing all production steps in a single location) rather than the start and stop steps of batch processing across dozens of locations that currently dominates the industry. It promises to save money and reduce waste and toxic pollution.

Civica has a drug finishing and packaging facility across the street from the future Phlow plant and has agreed to long term purchase commitments for the APIs. Drugs would be shipped directly to Civica member hospitals, simplifying distribution for enhanced security at reduced costs.

\section{Protections}

US efforts are not just about stimulating drug production and manufacturing infrastructure, they are also about protecting the domestic market and assuring quality control through Food and Drug Administration (FDA) inspection. A funding bill passed by the US House of Representatives for the fiscal year beginning 1 October would empower the FDA “to develop a plan to identify, detain, and refuse the import of FDA-regulated products from a foreign establishment that did not allow physical access to FDA investigators," and increases funding for overseas inspections of facilities. $^{7}$

Nicolette Louissant is concerned that such overly nationalistic approaches might be counterproductive. "We could unwittingly create more strains in the supply chain [with too many countries] producing the same product where there may not even be a demand for those products.” That is not sustainable says the executive director of Healthcare Ready, a coalition concerned with supply chain issues.

But Ronald Piervincenzi, CEO of the United States Pharmacopeia, a non-profit that sets manufacturing quality standards used worldwide, is optimistic, believing that the US can become more competitive in its major problem area-generic drugs-by embracing continuous flow production techniques such as those envisioned for Phlow. Long term agreements of five years or more to purchase set amounts of drugs at a set price can increase the willingness of manufacturers to make those types of investments in capacity, and tax or investment incentives by government can speed that transition.

Piervincenzi says resilient supply chains consist of a variety of companies and production locations that minimizes risk of a storm, contamination, or faltering leadership completely knocking out the supply of a drug. That's often done by diversifying globally, but it could be done nationally.

Joseph Glajch says it "is going to take a combination of the willingness of government to do some support, the willingness of insurers and ultimately consumers to pay slightly more for the drugs that they may have gotten for relatively cheap now, some combination of that, and perhaps the buyers being willing to commit to longer term contract from US based companies."

Pharmaceutical industry veteran B Frank Gupton, now head of Medicines for All, a non-profit research group at Virginia Commonwealth University, says it took 20-30 years for the US to offshore its healthcare: "It is going to take a while for us to bring it back. The question is, do we have the staying power to do that?"

Competing interests: I have read and understood BMJ policy on declaration of interests and have no relevant interests to declare.

Provenance and peer review: Commissioned; not externally peer reviewed.

White House. Executive order on ensuring essential medicines, medical countermeasures, and critical inputs are made in the United States. 2020. https://www.whitehouse.gov/presidentialactions/executive-order-ensuring-essential-medicines-medical-countermeasures-critical-inputsmade-united-states/.

2 Hains T. Author Rosemary Gibson: US is now dependent on China for vital medicine. Real Clear Politics 2018. https://www.realclearpolitics.com/video/2018/04/23/author_rosemary_gibson_us_is_becoming_dependent_on_china_for_vital_medicine.html.

3 Chaudhuri P. The world's pharmacy: Some facts about generic drugs answered. Telegraph Online 2020. https://www.telegraphindia.com/science-tech/the-worlds-pharmacy-some-facts-aboutgeneric-drugs-answered/cid/1766282.

4 Slater J. After deadly border clash, India faces uncomfortable truths about its reliance on China. Washington Post2020. https://www.washingtonpost.com/world/asia_pacific/india-china-borderclash-trade-imports/2020/06/26/4eca1f76-b4e2-11ea-9a1d-d3db1cbe07ce_story.html.

5 Roehr B. US hospitals launch non-profit generic drug producer to counter rising prices. BMJ 2018;362:k3840. doi: 10.1136/bmj.k3840 pmid: 30194067

6 Liljenquist D, Bai G, Anderson GF. Addressing generic-drug market failures - the case for establishing a nonprofit manufacturer. N Engl J Med 2018;378:1857-9. doi: 10.1056/NEJMp1800861 pmid: 29768140

7 Oakes K. \$3.2 billion FDA budget clears US House. Regulatory Focus 2020. https://www.raps.org/news-and-articles/news-articles/2020/7/32-billion-fda-budget-clears-us-
house. 